Check for updates

Cite this: RSC Adv., 2017, 7, 35962

\section{Bioreactors for low-pH iron(II) oxidation remove considerable amounts of total iron $\uparrow$}

\author{
Yizhi Sheng, (ID*abc Bradley Kaley, ${ }^{a}$ Kyle Bibby, ${ }^{d}$ Christen Grettenberger, ${ }^{e}$ \\ Jennifer L. Macalady, ${ }^{e}$ Guangcai Wang ${ }^{b}$ and William D. Burgos (DD ${ }^{a}$
}

Low-pH Fe(॥) oxidation occurs naturally in certain acid mine drainage (AMD) systems and can be incorporated into passive treatments by enhancing the development of terraced iron formations (TIFs). For extremely difficult-to-treat AMD (very low pH, high concentrations of Fe(॥) and associated metals), an active treatment bioreactor may be required. Based on field studies of eight low-pH TIF sites in the Appalachian Bituminous Coal Basin, US, two sites that displayed the fastest and regional-average rates of Fe(II) oxidation were selected to enrich for Fe(॥)-oxidizing microbes in chemostatic bioreactors with controlled geochemistry. After 74 to 128 days of fed-batch enrichment periods and a series of hydraulic residence time (HRT) experiments, four bioreactors (two for each site) were operated in flow-through mode through a series of $\mathrm{pH}$ set-points ( $\mathrm{pH} 2.1$ to 4.2; fixed [Fe(॥)] in) or influent Fe(॥) concentrations (80 to $2400 \mathrm{mg} \mathrm{L}^{-1}$; fixed $\mathrm{pH}$ ) for an additional 52 to 138 days using site-specific anoxic AMD as influent. Fe(I) oxidation kinetics in bioreactors were remarkably similar from two sites that displayed significantly different field rates. Fe(॥) oxidation rates were faster at high flow rate, low $\mathrm{pH}$ and high $\mathrm{Fe}(॥)$ concentrations, consistent with field results. A three-parameter dual-Monod rate law was developed to describe Fe(॥) oxidation kinetics solely based on $\mathrm{pH}$ and Fe(॥) concentration, and agreed well with some other bioreactor and field studies. Importantly, these bioreactors also effectively removed total Fe at rates 7 to 20 times better than passive treatment settling ponds and TIFs sites, at optimal pH between 2.9 to 3.3. All of these results point to the promise of bioreactors enriched by natural-occurring acidophilic Fe(॥)-oxidizing microbes for AMD treatment.
Received 31st March 2017 Accepted 10th July 2017 DOI: $10.1039 / c 7 r a 03717 a$ rsc.li/rsc-advances tree, mine drainage with high-acidity, high-metals and lowoxygen is essentially classified as un-treatable. However, biologically-mediated low-pH Fe(II) oxidation can promote the oxidative precipitation of Fe(III) minerals (e.g., schwertmannite and goethite) and remove considerable amounts of total Fe. ${ }^{6-10}$ This process can take a high-acidity, high-metals discharge and effectively change it into a moderate-acidity (still low $\mathrm{pH}$ ), low-metals discharge. These chemical transformations effectively produce mine water that can be reclassified as treatable by conventional technologies. This reclassification can be critical for watershed groups when applying for state or federal funds for reclamation of abandoned mine lands.

We have measured rates of low-pH Fe(II) oxidation at several \footnotetext{
field sites in the Appalachian Bituminous Coal Basin and in the Iberian Pyrite Belt. ${ }^{8}$ Rates were measured across both natural terraced iron formations (TIFs) and 'engineered' TIFs. An engineered TIF is often just a lined channel that allows for shallow sheet-flow conditions. The fastest rates of Fe(II) oxidation were measured at the sites with lowest $\mathrm{pH}$ values. Field rates ranged from $16.0 \times 10^{-7}$ to $97.0 \times 10^{-7} \mathrm{~mol} \mathrm{Fe(II)} \mathrm{L}^{-1} \mathrm{~s}^{-1}$. Significant removal of total Fe occurred across these TIFs even though the $\mathrm{pH}$ values tended to decrease.

${ }^{a}$ Department of Civil and Environmental Engineering, The Pennsylvania State University, 212 Sackett Building, University Park, PA 16802, USA

${ }^{b}$ School of Water Resources and Environment, China University of Geosciences, Beijing 100083, China.E-mail: shengyz@cugb.edu.cn

'School of Environment, Tsinghua University, Beijing 100084, China

${ }^{d}$ Department of Civil and Environmental Engineering, University of Pittsburgh, 709 Benedum Hall, Pittsburgh, Pennsylvania 15261, USA

${ }^{e}$ Department of Geosciences, The Pennsylvania State University, 503 Deike Building, University Park, PA 16802, USA

$\dagger$ Electronic supplementary information (ESI) available. See DOI:
} 10.1039/c7ra03717a 
Rates of low-pH Fe(II) oxidation have also been measured in engineered bioreactors. Both suspended-growth and fixed-film bioreactor configurations have been used. Fixed-film configurations tend to maintain higher biomass concentrations compared to suspended-growth systems. Hedrich and Johnson $^{10}$ designed an AMD remediation system that integrated lowpH Fe(II) oxidation and Fe removal in a multi-reactor system. The fastest rates of Fe(II) oxidation occurred in a suspendedgrowth bioreactor enriched with a pure culture of the $\mathrm{Fe}(\mathrm{II})$ oxidizer Ferrovum myxofaciens. Heinzel et al., ${ }^{11,12}$ Janneck et al. ${ }^{13}$ and Tischler et al. ${ }^{\mathbf{1 4}}$ all measured Fe(II) oxidation rates in a pilotscale bioreactor equipped with porous fixed-film media that developed a natural mixed community of Fe(II)-oxidizers, ultimately dominated by 'Ferrovum-like' species. Rates from these particular bioreactors ranged from $0.35 \times 10^{-7}$ to $6.5 \times$ $10^{-7}$ mol Fe(II) $\mathrm{L}^{-1} \mathrm{~s}^{-1}$.

Rates of low-pH Fe(II) oxidation measured in flow-through bioreactors have been exceptionally variable. ${ }^{\mathbf{1 0 - 1 8}}$ Reported rates have ranged over three orders of magnitude, from $0.35 \times$ $10^{-7}$ to $560 \times 10^{-7} \mathrm{~mol} \mathrm{Fe}(\mathrm{II}) \mathrm{L}^{-1} \mathrm{~s}^{-1}$. Much of this variation is caused by different operational conditions. For example, influent $\mathrm{pH}$ values have ranged from 1.25 to 5.80 , influent $\mathrm{Fe}$ (II) concentrations have ranged from 56 to $25000 \mathrm{mg} \mathrm{L}^{-1}$, reactor temperatures have ranged from 13 to $33{ }^{\circ} \mathrm{C}$, hydraulic residence times have ranged from 0.5 to 10 hours, microbial inoculum has varied from pure cultures to natural mixed communities, and biomass concentrations have ranged over four orders of magnitude $\left(5.1 \times 10^{4}\right.$ to $7 \times 10^{8}$ cell per $\left.\mathrm{mL}\right)$.

The objectives of this research were to develop generalized rate laws for biological low-pH Fe(II) oxidation, and optimize the hydrogeochemical conditions for both Fe(II) oxidation and total Fe removal in active treatment bioreactors. Based on previous field research, we selected two sites in the Appalachian Bituminous Coal Basin that displayed the fastest (Scalp Level) and regional-average (Brubaker Run) rates of $\mathrm{Fe}(\mathrm{II})$ oxidation. We enriched Fe(II)-oxidizing microbes from both sites and then used chemostatic bioreactors to measure Fe(II) oxidation and total $\mathrm{Fe}$ removal kinetics as a function of $\mathrm{pH}$ and influent $\mathrm{Fe}$ (II) concentration.

\section{Methods and materials}

\subsection{Site description and sampling}

Scalp Level is a small AMD spring $\left(<0.5 \mathrm{~L} \mathrm{~s}^{-1}\right)$ emanating from an abandoned underground coal mine (Mine \#29 in Scalp Level, PA). The AMD flows quickly down a narrow scoured channel on a steep hillside adjacent to a large area of un-reclaimed mine spoils. In addition to fast rates of Fe(II) oxidation, Scalp Level is unique because the $\mathrm{pH}$ of the water increases as it travels across the site. The rates of Fe(II) oxidation measured at Brubaker Run were very close to the average for the whole Appalachian region. Brubaker Run is a large discharge $\left(\sim 9.5 \mathrm{~L} \mathrm{~s}^{-1}\right)$ emanating from an abandoned underground clay mine (Dean Clay Mine near Dean, PA). Surface coal mines located above the Dean Clay Mine breached the roof of the clay mine such that it now serves as the discharge location of acidic coal mine drainage. The AMD flows downhill in a highly uncontrolled multi-directional manner forming a large TIF $\left(6000 \mathrm{~m}^{2}\right)$. Site information (Table 1) and photographs (Fig. S1) are provided in the ESI. $\dagger$

Sediment samples were collected from each site as sources for Fe(II)-oxidizing microbes. Sediments were collected from the bottom of pools along the AMD flow paths. Sediments were collected downstream of the artesian discharges where the AMD had become well aerated. Sediments were collected by carefully cutting and prying out intact pieces from the top $2 \mathrm{~cm}$ of the stream bed. Sediments were transported to the lab and stored at $4{ }^{\circ} \mathrm{C}$ for no longer than one week before use.

Water was collected from each site for microbial enrichments and as influent to the bioreactors. Water was collected from the anoxic artesian springs in 12 to $50 \mathrm{~L}$ plastic containers. Containers were filled with little or no headspace. A total of 400 to $500 \mathrm{~L}$ of water were collected per collection trip (every 10 to 15 d) - enough water to operate the bioreactors for two weeks. Immediately upon arrival to the lab, all water was filtered (0.2 $\mu \mathrm{m}$ sterile bottle-top filters) into plastic containers, sparged with $\mathrm{N}_{2}$, wrapped in $\mathrm{Al}$ foil, and stored at $4{ }^{\circ} \mathrm{C}$. Water was stored for no longer than one week before use.

\subsection{Enrichment of Fe(II)-oxidizing microbes}

Mixed cultures of naturally-occurring microbes were enriched from the sediments from each site before any flow-through experiments were conducted. To develop enrichment cultures, $100 \mathrm{~g}$ of moist sediment was mixed with $1 \mathrm{~L}$ of $0.1 \%(\mathrm{~m} / \mathrm{v})$ sodium pyrophosphate (adjusted to $\mathrm{pH} 3.5$ with sulfuric acid). This suspension was stirred at $400 \mathrm{rpm}$ for $30 \mathrm{~min}$ to separate cells from the sediment. ${ }^{19}$ After $30 \mathrm{~min}$, the suspension was allowed to settle and then $900 \mathrm{~mL}$ of the cell-containing supernatant was poured into a sterile $3 \mathrm{~L}$ chemostat reactor vessel (Eppendorf BioFlo®/Celligen ${ }^{\circledR} 115$ Fermentor). The volume of the liquid in the chemostat was increased to $2.0 \mathrm{~L}$ by adding filtered site water. During this time the $\mathrm{pH}$ set-point of the chemostats were $\mathrm{pH} 2.7$ for the Scalp Level chemostat or $\mathrm{pH}$

Table 1 Geochemical characteristics and Fe(॥) oxidation rates from the two field sites $^{a}$

\begin{tabular}{|c|c|c|}
\hline Parameter & Scalp Level & Brubaker Run \\
\hline \multirow[t]{2}{*}{ Latitude/longitude } & $40^{\circ} 14^{\prime} 43.72^{\prime \prime} \mathrm{N}$ & $40^{\circ} 37^{\prime} 1.42^{\prime \prime} \mathrm{N}$ \\
\hline & $78^{\circ} 51^{\prime} 33.18^{\prime \prime} \mathrm{W}$ & $78^{\circ} 28^{\prime} 35.76^{\prime \prime} \mathrm{W}$ \\
\hline Temp $\left({ }^{\circ} \mathrm{C}\right)$ & $13.3 \pm 0.67$ & $11.0 \pm 0.26$ \\
\hline $\mathrm{DO}\left(\mathrm{mg} \mathrm{L}^{-1}\right)$ & $0.06 \pm 0.05$ & $0.06 \pm 0.05$ \\
\hline ORP (mV) & $386 \pm 39$ & $348 \pm 37$ \\
\hline Conductivity $\left(\mu \mathrm{S} \mathrm{cm}^{-1}\right)$ & $2010 \pm 24$ & $1690 \pm 236$ \\
\hline $\mathrm{pH}$ & $2.89 \pm 0.08$ & $3.37 \pm 0.15$ \\
\hline Dissolved total $\mathrm{Fe}\left(\mathrm{mg} \mathrm{L}^{-1}\right)$ & $97.4 \pm 9.43$ & $118 \pm 27.9$ \\
\hline Dissolved Fe(II) (mg L $\left.{ }^{-1}\right)$ & $92.3 \pm 11.9$ & $114 \pm 28.4$ \\
\hline $\mathrm{SO}_{4}{ }^{2-}\left(\mathrm{mg} \mathrm{S} \mathrm{L}^{-1}\right)$ & $429 \pm 34$ & $381 \pm 89$ \\
\hline Mean acidity $\left(\mathrm{mg} \mathrm{L}^{-1}\right.$ as $\left.\mathrm{CaCO}_{3}\right)$ & 357 & 360 \\
\hline$k_{1 \text { st,field }}\left(\min ^{-1}\right)$ & $0.465 \pm 0.029$ & $0.070 \pm 0.032$ \\
\hline$R_{\text {Zero,field }}\left(\mathrm{mol} \mathrm{L}^{-1} \mathrm{~s}^{-1}\right) \times 10^{-7}$ & $97.0 \pm 28.3$ & $16.0 \pm 6.10$ \\
\hline$n$ & 3 & 5 \\
\hline
\end{tabular}


2.9 for the Brubaker Run chemostats, the stirring rate was $50 \mathrm{rpm}$, and the temperature was $20^{\circ} \mathrm{C}$. The headspace of the reactor was open to the ambient atmosphere and air was continuously sparged into the water. Ferrous sulfate $\left(\mathrm{FeSO}_{4}\right.$ $\cdot 7 \mathrm{H}_{2} \mathrm{O}$ ) was discontinuously added to the reactor as the primary substrate to enrich for $\mathrm{Fe}(\mathrm{II})$-oxidizing microbes whenever the dissolved Fe(II) concentration decreased below $30 \mathrm{mg} \mathrm{L}^{-1}$.

After a common fed-batch enrichment period (80 d for Scalp Level; $30 \mathrm{~d}$ for Brubaker Run), each enrichment culture was divided for the $\mathrm{pH}$-series and the $\mathrm{Fe}(\mathrm{II})$-series experiments. The $\mathrm{pH}$-series reactor was operated in fed-batch mode for an additional $17 \mathrm{~d}$ (97 d total) in Scalp Level and $44 \mathrm{~d}$ (74 d total) in Brubaker Run, and the Fe(II)-series reactors was operated in fedbatch mode for an additional $48 \mathrm{~d}$ (128 d total) in Scalp Level and $83 \mathrm{~d}$ (113 d total) in Brubaker Run. Automated control components of the bioreactors maintained a constant $\mathrm{pH}$, temperature and mixing speed, and continuously recorded DO. Feedback controls between the $\mathrm{pH}$ meter in the reactor and two peristaltic pumps delivering either $0.2 \mathrm{~N} \mathrm{H}_{2} \mathrm{SO}_{4}$ or $0.2 \mathrm{~N} \mathrm{NaOH}$ were used to maintain any desired $\mathrm{pH}$ set-point. The reactor control system also recorded the rate and volume of titrant $\left(\mathrm{H}_{2} \mathrm{SO}_{4}, \mathrm{NaOH}\right)$ addition. A one-pass, tap water-fed, cooling coil within the reactor and a thermal jacket around the reactor were used to maintain the reactor temperature.

\subsection{Fe(II) oxidation in flow-through bioreactors}

During all flow-through experiments, the influent water tank was wrapped in Al foil and continuously purged with 100\% $\mathrm{N}_{2}(\mathrm{~g})$, and $\mathrm{FeSO}_{4}$ was added to yield the desired influent dissolved Fe(II) concentration. A peristaltic pump conveyed the influent through the reactor and maintained the desired hydraulic residence time (HRT). All reactor control components were initially unchanged from the fed-batch mode. For each operational set-point, the bioreactor was operated until it achieved a pseudo-steady state condition with respect to maintaining a near-constant ratio of effluent to influent dissolved $\mathrm{Fe}$ (II) concentrations (within $\pm 5 \%$ of the final sampling event for each geochemical-series). The operational set-point was then incrementally and sequentially changed and the system was allowed to establish a new steady-state condition.

Preliminary experiments were conducted to evaluate the effect of HRT on bioreactor performance. Experiments began at the longest HRT ( $24 \mathrm{~h}$ ) to better provide for the adaptation from fed-batch to flow-through conditions (e.g., to minimize cell washout). The HRTs were sequentially decreased from 24 to 12 , $6,3,1,0.75$ and $0.5 \mathrm{~h}$. The operating time for each HRT set-point ranged from 5 to 10 pore volumes. For some system variables (e.g., HRT with the Brubaker Run bioreactor) we chose to sequentially "reverse" the set-points of the bioreactor to evaluate how reactor performance would recover and whether the steady state conditions would be repeatable. All subsequent flow-through experiments were conducted at an HRT of $6 \mathrm{~h}$.

The $\mathrm{pH}$-series experiments began at the $\mathrm{pH}$ of enrichment (pH 2.7 for the Scalp Level bioreactor; pH 2.9 for the Brubaker Run bioreactor). For the Scalp Level bioreactor, the pH setpoints varied sequentially from $\mathrm{pH} 2.7$ to $2.4,2.1,2.4,2.7,3.0$,
3.3, 3.6, 3.9 and 4.2. For the Brubaker Run bioreactor, the $\mathrm{pH}$ set-points varied sequentially from $\mathrm{pH} 2.9$ to 2.6, 2.3, 2.6, 2.9, 3.2, 3.5, 3.8, 4.1, 3.8 and 3.5. The influent Fe(II) concentrations averaged $293 \pm 28.1 \mathrm{mg} \mathrm{L}^{-1}$ in the Scalp Level bioreactor and $309 \pm 14.0 \mathrm{mg} \mathrm{L}^{-1}$ in the Brubaker Run bioreactor.

The influent $\mathrm{Fe}(\mathrm{II})$-series experiments began at the influent $\mathrm{Fe}(\mathrm{II})$ concentration of enrichment $\left(\sim 300 \mathrm{mg} \mathrm{L}^{-1}\right.$ for both bioreactors). For the Scalp Level bioreactor, the influent Fe(II) concentrations varied sequentially from $\sim 300$ to $60,300,600$, 1200,2400 and $1200 \mathrm{mg} \mathrm{L}^{-1}$ while the $\mathrm{pH}$ was maintained at $\mathrm{pH}$ 2.7. For the Brubaker Run bioreactor, the influent $\mathrm{Fe}$ (II) concentrations varied sequentially from $\sim 300$ to $80,300,600$, 1200, 2400, 1200 and $600 \mathrm{mg} \mathrm{L}^{-1}$ while the $\mathrm{pH}$ was maintained at $\mathrm{pH} 2.9$.

The operating time for each $\mathrm{pH}$ and influent $\mathrm{Fe}(\mathrm{II})$-series setpoint ranged from 20 to 50 pore volumes for the Brubaker Run bioreactor (a total of 440 pore volumes for $\mathrm{pH}$-series and 280 pore volumes for influent $\mathrm{Fe}(\mathrm{II})$-series), while was fixed at $\sim 50$ pore volumes for the Scalp Level bioreactor (a total of 540 pore volumes for $\mathrm{pH}$-series and 375 pore volumes for influent $\mathrm{Fe}(\mathrm{II})$ series). Abiotic control experiments were conducted for both sites using sterile, un-inoculated reactors operated at every operational set-point.

Biomass in both suspended and attached growth biofilm were collected before switched to the next geochemical conditions. Sludge samples in the bottom of the bioreactors were collected at selected geochemical conditions for mineralogical analysis.

\subsection{Kinetic modeling of $\mathrm{Fe}(\mathrm{II})$ oxidation and $\mathrm{Fe}(\mathrm{T})$ removal}

Assuming that the chemostat operated as a completely-mixed flow-through reactor at steady state, the rate of $\mathrm{Fe}(\mathrm{II})$ oxidation $\left(R_{\mathrm{Fe}(\mathrm{II})}\right.$; $\left.\mathrm{mol} \mathrm{Fe}(\mathrm{II}) \mathrm{L}^{-1} \mathrm{~s}^{-1}\right)$ was calculated as:

$$
R_{\mathrm{Fe}(\mathbf{I I})}=-\frac{\mathrm{d}[\mathrm{Fe}(\mathbf{I I})]}{\mathrm{d} t}=\frac{\left(\left[\mathrm{Fe}(\mathbf{I I})_{\text {in }}\right]-\left[\mathrm{Fe}(\mathbf{I I})_{\text {out }}\right]\right)}{\mathrm{HRT}}
$$

where $\left[\mathrm{Fe}(\mathrm{II})_{\text {in }}\right]$ is the influent dissolved $\mathrm{Fe}(\mathrm{II})$ concentration (mol $\left.\mathrm{L}^{-1}\right),\left[\mathrm{Fe}(\mathrm{II})_{\text {out }}\right]$ is the effluent dissolved Fe(II) concentration (mol $\mathrm{L}^{-1}$ ), and HRT is in seconds. Pesic et al. ${ }^{20}$ and Kirby et al. ${ }^{21}$ have proposed a rate formulation for biological Fe(II) oxidation similar to:

$$
R_{\mathrm{Fe}(\mathbf{I I})}=-\frac{\mathrm{d}[\mathrm{Fe}(\mathbf{I I})]}{\mathrm{d} t}=k C_{\text {bact }}\left[\mathrm{O}_{2}\right][\mathrm{Fe}(\mathbf{I I})]\left[\mathrm{H}^{+}\right]
$$

where $k$ is the rate constant $\left(\mathrm{L}^{3} \mathrm{mg}^{-1} \mathrm{moL}^{-2} \mathrm{~s}^{-1}\right), C_{\text {bact }}$ is the concentration of $\mathrm{Fe}(\mathrm{II})$-oxidizing bacteria ( $\mathrm{mg} \mathrm{L}^{-1}$, dry weight), $\left[\mathrm{O}_{2}\right]$ is the dissolved or atmospheric equivalent concentration of oxygen $\left(\mathrm{mol} \mathrm{L}^{-1}\right)$, and $[\mathrm{Fe}(\mathrm{II})]$ and $\left[\mathrm{H}^{+}\right]$are in $\mathrm{mol} \mathrm{L}^{-1}$. Because $C_{\text {bact }}$ remained essentially constant, $\mathrm{O}_{2}$ was never limiting (e.g., always well above $\left.0.64-2.0 \mathrm{mg} \mathrm{L}^{-1}\right),{ }^{15,22}$ and $\mathrm{Fe}(\mathrm{II})$ and $\mathrm{H}^{+}$were systematically varied in these bioreactors, we simplified and recast eqn (2) in a dual-Monod form as:

$$
R_{F e(\text { II })}=k_{\text {bio }}^{*}\left(\frac{\left[\mathrm{H}^{+}\right]}{K_{\mathrm{H}^{+}}+\left[\mathrm{H}^{+}\right]}\right)\left(\frac{[\mathrm{Fe}(\mathbf{I I})]}{K_{\mathrm{Fe}(\mathrm{II})}+[\mathrm{Fe}(\mathbf{I I})]}\right)
$$

where $k_{\mathrm{bio}}^{*}$ is the lumped rate constant ( $\left.\mathrm{mol} \mathrm{Fe(II)} \mathrm{L}^{-1} \mathrm{~s}^{-1}\right), K_{\mathrm{H}^{+}}$is the half-saturation coefficient with respect to $\mathrm{H}^{+}\left(\mathrm{mol} \mathrm{H}^{+} \mathrm{L}^{-1}\right)$, 
and $K_{\mathrm{Fe}(\mathrm{II})}$ is the half-saturation coefficient with respect to dissolved $\mathrm{Fe}(\mathrm{II})$ (mol $\mathrm{Fe}(\mathrm{II}) \mathrm{L}^{-1}$ ). $K_{\mathrm{H}^{+}}$was determined from the $\mathrm{pH}$ series experiments, $K_{\mathrm{Fe}(\mathrm{II})}$ was determined from the Fe(II)-series experiments, and $k_{\mathrm{bio}}^{*}$ was determined from all of the bioreactor experiments [using the pre-determined values of $K_{\mathrm{H}^{+}}$and $K_{\mathrm{Fe} \text { (II)] }}$. Because geochemical gradients across natural TIFs are similar to one another, ${ }^{7-9,23,24}$ this rate law was also used to predict rates obtained from field sites.

Using a common metric for the performance of AMD passive treatment systems ${ }^{25}$ the removal rate of total Fe was calculated as:

$$
\mathrm{GDM}=\left(\left[\mathrm{Fe}(\mathrm{T})_{\text {in }}\right]-\left[\mathrm{Fe}(\mathrm{T})_{\text {out }}\right]\right) \times Q / A
$$

where GDM is the $\mathrm{Fe}(\mathrm{T})$ removal rate $\left(\mathrm{g} \mathrm{Fe}(\mathrm{T}) \mathrm{d}^{-1} \mathrm{~m}^{-2}\right)$ in terms of the plan-view area of the treatment system $\left(A ; \mathrm{m}^{2}\right),\left[\mathrm{Fe}(\mathrm{T})_{\text {in }}\right]$ is the influent total $\mathrm{Fe}$ concentration $\left(\mathrm{g} \mathrm{L}^{-1}\right),\left[\mathrm{Fe}(\mathrm{T})_{\text {out }}\right]$ is the effluent total Fe concentration $\left(\mathrm{g} \mathrm{L}^{-1}\right)$, and $Q$ is the reactor flow rate $\left(\mathrm{L} \mathrm{d}^{-1}\right)$.

\subsection{Analytical methods}

During all experiments, data-logging software was used to record all of the operating conditions (time, $\mathrm{pH}$, temperature, mixer speed, and volume of titrant addition) at a user-specified time interval of $1 \mathrm{~min}$. Fe was measured as total and dissolved based on $0.20 \mu \mathrm{m}$ filtration. Dissolved Fe(II) was measured using the ferrozine assay. ${ }^{26}$ Total $\mathrm{Fe}(\mathrm{T})$ was measured using the ferrozine assay after reduction by $0.5 \mathrm{M}$ hydroxylamine in $0.5 \mathrm{M}$ hydrochloric acid. ${ }^{27}$ Rates of Fe(II) oxidation were based on dissolved $\mathrm{Fe}(\mathrm{II})$ concentrations. Rates of $\mathrm{Fe}(\mathrm{T})$ removal were based on total (i.e., unfiltered) $\mathrm{Fe}(\mathrm{T})$ concentrations. Biomass samples were collected from the reactor wall and from the suspension at the end of the fed-batch enrichment mode and at the end of each steady state condition. Biomass concentrations were determined based on protein (Bio-Rad protein assay kit that uses Coomassie ${ }^{\circledR}$ Brilliant Blue G-250 dye). An area of at least $1 \mathrm{~cm}^{2}$ of biofilm was scraped from the wall of the reactor or $135 \mathrm{~mL}$ of reactor liquid was collected. Sludge samples were airdried and sieved $(<2 \mathrm{~mm})$ prior to analysis of mineralogical characterization. Geochemical modelling were carried out in Geochemist's Workbench Essentials software.

\section{Results and discussion}

The enrichment of Fe(II)-oxidizing microbes from surface sediments collected from each site displayed similar characteristics. During the fed-batch enrichment cycle it took 10 to $20 \mathrm{~d}$ for the system to begin to rapidly and completely oxidize the $\mathrm{Fe}$ (II) spiked into the reactor (ESI Fig. S2 $\dagger$ ). After 74 to $128 \mathrm{~d}$ of flowthrough operation, the rates of $\mathrm{Fe}(\mathrm{II})$ oxidation consistently reached $0.41 \times 10^{-7}$ to $1.78 \times 10^{-7} \mathrm{~mol} \mathrm{Fe}(\mathrm{II}) \mathrm{L}^{-1} \mathrm{~s}^{-1}$, and the rates of total $\mathrm{Fe}(\mathrm{T})$ removal consistently reached $0.35 \times 10^{-7}$ to $1.37 \times 10^{-7} \mathrm{~mol} \mathrm{Fe}(\mathrm{T}) \mathrm{L}^{-1} \mathrm{~s}^{-1}$ (equivalent to 13.7 to $53.7 \mathrm{~g} \mathrm{Fe}(\mathrm{T})$ $\mathrm{d}^{-1} \mathrm{~m}^{-2}$ using eqn (4)) in the Scalp Level and Brubaker Run bioreactors.

\section{1 $\mathrm{Fe}(\mathrm{II})$ oxidation in flow-through bioreactors}

The HRT in the bioreactor affected the extent of Fe(II) oxidation (Fig. 1). The final sampling event for each HRT set-point was assumed to represent steady state for that condition. The enlarged symbols in Fig. 1A and B denote those measurements within $\pm 5 \%$ of the steady state concentration (the ratio of effluent and influent $\mathrm{Fe}(\mathrm{II})$ concentration, $\left.C_{\text {out }} / C_{\text {in }}\right)$. Average rates were then calculated at each denoted point within this operationally defined range of $\pm 5 \%$ in Fig. $1 \mathrm{C}$ and D. As the HRT was incrementally decreased, both the effluent Fe(II) and total Fe concentrations increased in both bioreactors. While rates of $\mathrm{Fe}(\mathrm{II})$ oxidation were fastest at low HRT values, the extent of $\mathrm{Fe}(\mathrm{II})$ oxidation was greatest at higher HRT values (Fig. 1C). Over $90 \%$ of the Fe(II) was oxidized for both Scalp Level and Brubaker Run bioreactors when HRT was below 6 h. Based on these preliminary experiments, all further experiments were conducted at an HRT of $6 \mathrm{~h}$.

$\mathrm{Fe}(\mathrm{II})$ oxidation in the reactors was completely due to microbial activity. At $\mathrm{pH}$ values of 2.1 to 4.2 , reported rates of abiotic homogeneous oxidation of $\mathrm{Fe}(\mathrm{II})$ by $\mathrm{DO}$ are negligible. ${ }^{28}$ While heterogeneous Fe(II) oxidation by DO could have been promoted by the accumulation of Fe(III) solids in the bioreactors, kinetic model calculations ${ }^{29}$ confirmed that the rate of this reaction was two to six orders of magnitude slower than the rates of $\mathrm{Fe}(\mathrm{II})$ measured in the bioreactors (ESI Fig. S3 $\dagger$ ). Abiotic control reactors confirmed that little Fe(II) was oxidized, where effluent $\mathrm{Fe}$ (II) concentrations averaged $>97 \%$ of influent $\mathrm{Fe}(\mathrm{II})$.

Rates of $\mathrm{Fe}(\mathrm{II})$ oxidation were fastest at the lowest $\mathrm{pH}$ setpoints and decreased as the $\mathrm{pH}$ of the system increased (Fig. 2). Over $90 \%$ of dissolved $\mathrm{Fe}(\mathrm{II})$ can be oxidized when $\mathrm{pH}$ $<2.4$ in Scalp Level bioreactor and when $\mathrm{pH}<2.6$ in Brubaker Run Bioreactor. Slower rates of $\mathrm{Fe}(\mathrm{II})$ oxidation at higher $\mathrm{pH}$ values were consistent with previous field measurements. ${ }^{8}$ Slower rates of $\mathrm{Fe}(\mathrm{II})$ oxidation at higher $\mathrm{pH}$ values were consistent with thermodynamic calculations that show the Gibbs free energy of Fe(II) oxidation becomes less negative as $\mathrm{pH}$ increases. ${ }^{30}$ Slower rates of $\mathrm{Fe}(\mathrm{II})$ oxidation at higher $\mathrm{pH}$ values was consistent with microbial community analysis that the relative abundance of acidophilic $\mathrm{Fe}(\mathrm{II})$-oxidizing bacteria (e.g., Ferrovum, Leptospirillum, Acidithiobacillus) decreased as $\mathrm{pH}$ increased. ${ }^{31,32}$ Slower rates of $\mathrm{Fe}(\mathrm{II})$ oxidation at higher $\mathrm{pH}$ values were also consistent with previous studies using suspendedgrowth and fixed-film bioreactors containing pure cultures of acidophilic Fe(II)-oxidizing bacteria. ${ }^{\mathbf{1 0 , 1 6}}$

Rates of $\mathrm{Fe}(\mathrm{II})$ oxidation in these laboratory systems were slower compared to rates measured at the corresponding field sites (Table 1). For example, the field-based Fe(II) oxidation rate measured at Scalp Level was $97.0 \pm 28.3 \times 10^{-7}$ mol Fe(II) $\mathrm{L}^{-1}$ $\mathrm{s}^{-1}(n=3)$ while the laboratory-based $\mathrm{Fe}(\mathrm{II})$ oxidation rates measured with the Scalp Level bioreactors ranged from $0.44 \times$ $10^{-7}$ to $7.7 \times 10^{-7}$ mol Fe(II) $\mathrm{L}^{-1} \mathrm{~s}^{-1}$. Similarly, the field-based $\mathrm{Fe}(\mathrm{II})$ oxidation rate measured at Brubaker Run was 16.0 \pm 6.1 $\times 10^{-7} \mathrm{~mol} \mathrm{Fe}(\mathrm{II}) \mathrm{L}^{-1} \mathrm{~s}^{-1}(n=5)$ while the laboratory-based $\mathrm{Fe}$ (II) oxidation rates measured with the Brubaker Run bioreactors ranged from $0.62 \times 10^{-7}$ to $5.8 \times 10^{-7} \mathrm{~mol} \mathrm{Fe}(\mathrm{II}) \mathrm{L}^{-1} \mathrm{~s}^{-1}$. Large area of TIFs containing abundance of Fe(II)-oxidizing bacterial 
community in certain AMD sites were taken to be a natural passive treatment systems as AMD flows downgradient. ${ }^{7-9}$

Laboratory-based rates of $\mathrm{Fe}(\mathrm{II})$ oxidation were more similar for these sites as compared to their corresponding field-based rates. The Fe(II) oxidation rate at Scalp Level was six times faster than the rate measured at Brubaker Run but likely caused by differences in the $\mathrm{pH}$ of the systems. The $\mathrm{pH}$ at Scalp Level was $2.89 \pm 0.08$ while the $\mathrm{pH}$ at Brubaker Run was $3.37 \pm 0.15$.
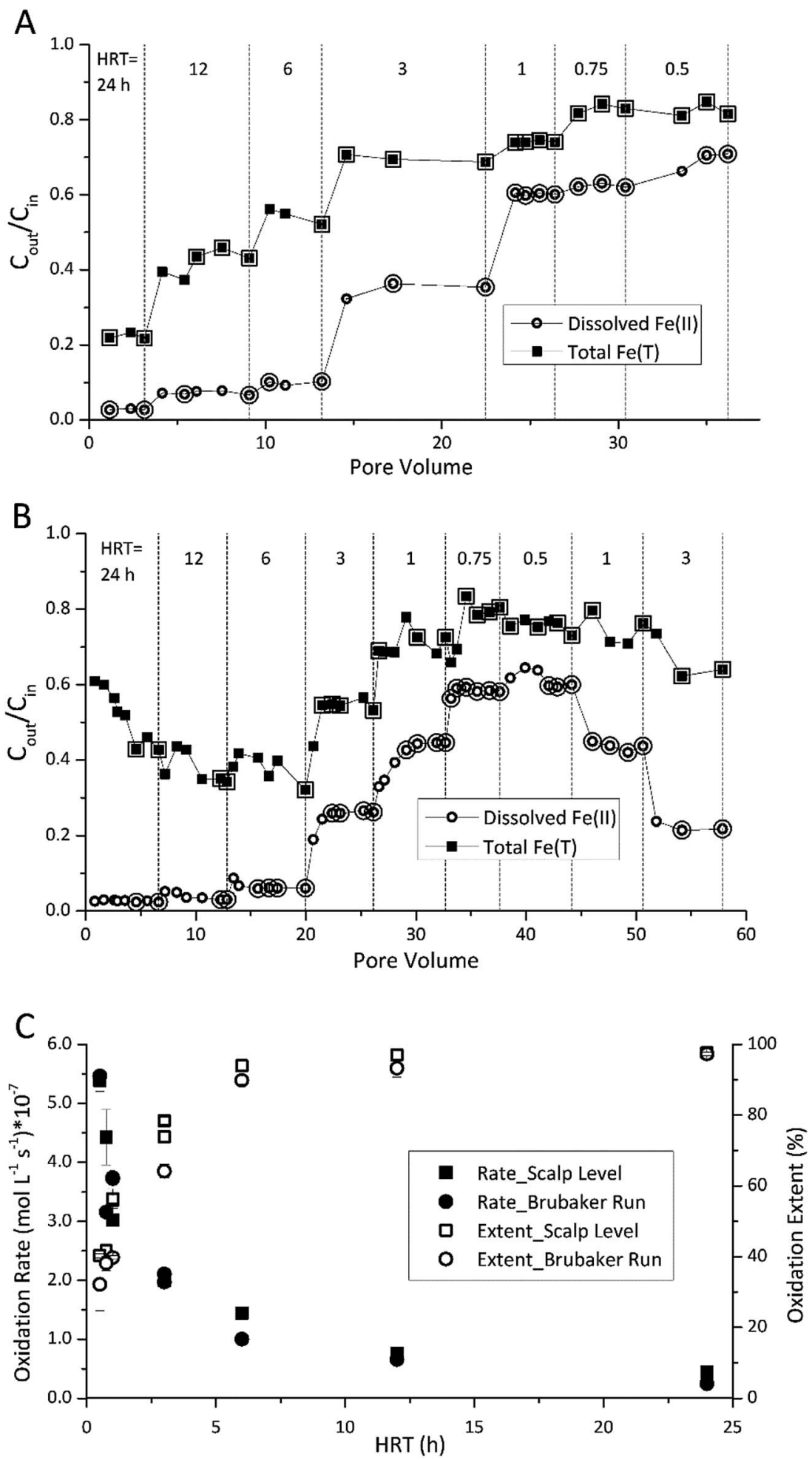

Fig. 1 Influence of hydraulic residence time (HRT) on Fe(॥) oxidation and Fe(T) removal. Different HRT set-points are denoted by vertical dashed lines. (A) Results obtained for the Scalp Level bioreactor $-\mathrm{pH}$ set-point $=2.7$ and $[\mathrm{Fe}(॥)]_{\text {in }}=150 \mathrm{mg} \mathrm{L}^{-1}$. (B) Results obtained for the Brubaker Run bioreactor $-\mathrm{pH}$ set-point $=2.9$ and $[\mathrm{Fe}(॥)]_{\text {in }}=200 \mathrm{mg} \mathrm{L}^{-1}$. Enlarged symbols in A and B denote points used to calculate rate and extent of Fe(॥) oxidation shown in (C). 

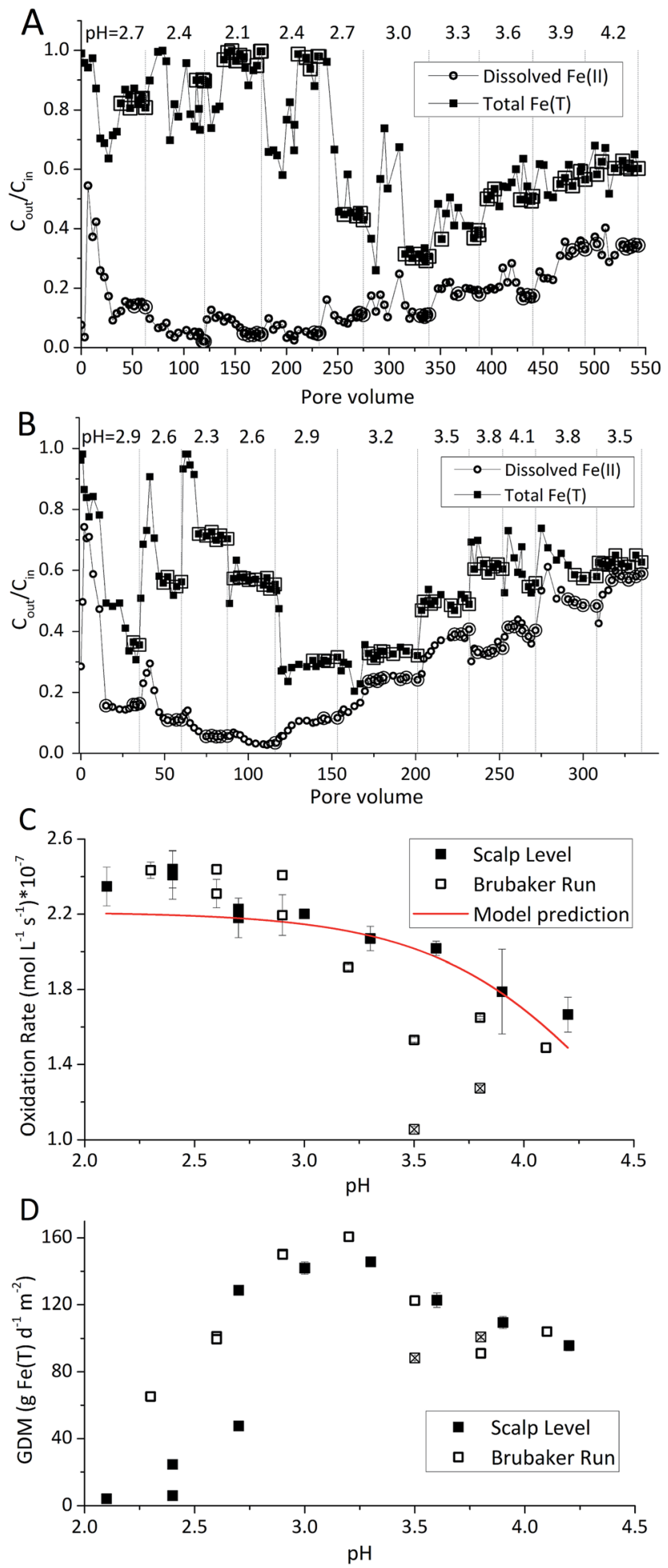

Fig. 2 Influence of $\mathrm{pH}$ set-point on Fe(॥) oxidation and Fe(T) removal obtained for the Scalp Level and Brubaker Run chemostats - hydraulic residence time of $6 \mathrm{~h}$ and $[\mathrm{Fe}(\mathrm{II})]_{\text {in }}$ of $300 \mathrm{mg} \mathrm{L}^{-1}$. Different $\mathrm{pH}$ set-points are denoted by vertical dashed lines. (A) Results obtained for the Scalp Level bioreactor as a function of pore volume. (B) Results obtained for the Brubaker Run bioreactor as a function of pore volume. Enlarged symbols in (A and B) denote steady-state points used to calculate rate of Fe(I) oxidation shown in (C) and rate of total Fe(T) removal in (D). Two operational conditions with the Brubaker Run chemostat (denoted with $\otimes)$ were excluded from model parameterization.
When operated under similar hydrogeochemical conditions (i.e., same HRT and $[\mathrm{Fe}(\mathrm{II})]_{\mathrm{in}}$, and similar $\left.\mathrm{pH}\right)$, the Fe(II) oxidation rates measured in the Scalp Level and Brubaker Run bioreactors were essentially the same. Encouragingly, the similarity in laboratory-based rates of $\mathrm{Fe}(\mathrm{II})$ oxidation from distinctly different sites should improve our ability to predict the kinetics of this process in upscaled active treatment systems.

The type of titrant $\left(\mathrm{H}_{2} \mathrm{SO}_{4}\right.$ or $\left.\mathrm{NaOH}\right)$ required to maintain the $\mathrm{pH}$-set points revealed conditions that favored the production of soluble versus insoluble $\mathrm{Fe}(\mathrm{III})$. Microbially-catalyzed $\mathrm{Fe}(\mathrm{II})$ oxidation can produce either soluble Fe(III) (eqn (5)) or insoluble Fe(III) (eqn (6)) according to:

$$
\begin{aligned}
& \mathrm{Fe}^{2+}+\frac{1}{4} \mathrm{O}_{2}+\mathrm{H}^{+}=\mathrm{Fe}^{3+}+\frac{1}{2} \mathrm{H}_{2} \mathrm{O} \\
& \mathrm{Fe}^{2+}+\frac{1}{4} \mathrm{O}_{2}+\frac{7}{32} \mathrm{SO}_{4}{ }^{2-}+\frac{17}{16} \mathrm{H}_{2} \mathrm{O} \\
& =\frac{25}{16} \mathrm{H}^{+}+\frac{1}{8} \mathrm{Fe}_{8} \mathrm{O}_{8}\left(\mathrm{SO}_{4}\right)_{1.75}(\mathrm{OH})_{4.5}
\end{aligned}
$$

where $\mathrm{Fe}_{8} \mathrm{O}_{8}\left(\mathrm{SO}_{4}\right)_{1.75}(\mathrm{OH})_{4.5}$ represents a nominal stoichiometry for schwertmannite. ${ }^{33}$

The Fe(III) precipitates should be essentially free of trace metal and metalloid contaminants. ${ }^{24}$ Geochemical modeling confirmed that schwertmannite was the predominant $\mathrm{Fe}(\mathrm{III})$ mineral formed in these bioreactor systems (ESI Fig. S4†), consistent with our field studies. ${ }^{7,24,34}$ Na-jarosite could have formed at the lowest $\mathrm{pH}$-set points. Model predictions accounted for variable concentrations of sulfate $(12.5-56 \mathrm{mM}$ from $\mathrm{FeSO}_{4}$ substrate and $\mathrm{H}_{2} \mathrm{SO}_{4}$ titrant) and $\mathrm{Na}(0.5-24 \mathrm{mM}$ from $\mathrm{NaOH}$ titrant) in the bioreactors. In eqn (5), acidity is consumed such that acid would have to be added to a chemostat to maintain the pH-set point. In eqn (6), acidity is produced such that base would have to be added to maintain the $\mathrm{pH}$-set point. In our experiments, $\mathrm{H}_{2} \mathrm{SO}_{4}$ was required to maintain all $\mathrm{pH}$ setpoints $<2.9$ (ESI Tables S1 and S2 $\dagger$ ). The production of soluble $\mathrm{Fe}(\mathrm{III})$, therefore, was favored at $\mathrm{pH}<2.9$. $\mathrm{NaOH}$ was required to maintain all $\mathrm{pH}$ set-points $>2.9$, thus the production of insoluble $\mathrm{Fe}(\mathrm{III})$ was favored at $\mathrm{pH}>2.9$.

\section{2 $\quad \mathrm{Fe}(\mathrm{T})$ removal in flow-through bioreactors}

The pH set-point of the bioreactor had a strong influence on the removal of total Fe (Fig. 2D). Due to the relatively high solubility of $\mathrm{Fe}(\mathrm{III})$ minerals (schwertmannite and jarosite) at low $\mathrm{pH}$, substantial removal of total Fe did not occur until the $\mathrm{pH}$ exceeded 2.7. The rates of total Fe removal were calculated using eqn (4) and the pseudo-steady state $\mathrm{Fe}(\mathrm{T})$ concentrations. The maximum removal of total Fe occurred between $\mathrm{pH} 2.90$ to 3.30. Up to $70 \%$ of total Fe can be removed from the solution (Fig. 2A and B). Below pH 2.90 the removal of $\mathrm{Fe}(\mathrm{T})$ was limited by the solubility of $\mathrm{Fe}(\mathrm{III})$ minerals precipitated in the bioreactor. Above $\mathrm{pH} 3.30$ the removal of $\mathrm{Fe}(\mathrm{T})$ was limited by the oxidation rate of Fe(II) (Fig. 2C). Total Fe removal in the Scalp Level bioreactor was lower than in the Brubaker Run bioreactor when $\mathrm{pH} \leq 2.9$. Lower Fe removal measured in the Scalp Level bioreactor was consistent with field studies. 
Under most operating conditions, these bioreactors far exceeded the performance of passive treatment operations for the removal of total Fe. For example, an aerobic pond built to capture Fe solids in a passive treatment system typically removes 15 to 20 grams of Fe per day per square meter of plan area (GDM) ${ }^{35,36}$ Aerobic wetlands typically remove 5 to 10 GDM of Fe. Natural and engineered terraced iron formations for low$\mathrm{pH}$ Fe(II) oxidation have been found to remove 0.1 to 8.7 GDM of iron. $^{7-9}$ The bioreactors used in this study removed up to 150 GDM of Fe in the pH-series experiments (Fig. 2D) and up to 400 GDM of Fe in the Fe(II)-series experiments (Fig. 3D).

The influent Fe(II) concentration had a direct effect on the rates of $\mathrm{Fe}(\mathrm{II})$ oxidation and $\mathrm{Fe}(\mathrm{T}$ ) removal (Fig. 3). Both of these rates increased as the influent Fe(II) concentration increased. At constant $\mathrm{pH}$ values (as controlled in these experiments), the rate of $\mathrm{Fe}(\mathrm{T})$ removal was directly proportional to the rates of $\mathrm{Fe}$ (II) oxidation and $\mathrm{Fe}$ (III) generation. As noted above, removal of 20 GDM of $\mathrm{Fe}$ is considered an adequate performance metric for passive treatment systems. This criteria was always exceeded when the $\mathrm{pH}$-set point was greater than 2.5 and when the influent $\mathrm{Fe}$ (II) concentration was greater than $50 \mathrm{mg} \mathrm{L}^{-1}$ (Fig. 2 and 3). However, the design, construction, and operation of a bioreactor are more costly than passive treatment unit operations. Therefore, a bioreactor for low-pH Fe(II) oxidation and $\mathrm{Fe}(\mathrm{T})$ removal would likely only become cost-effective for AMD
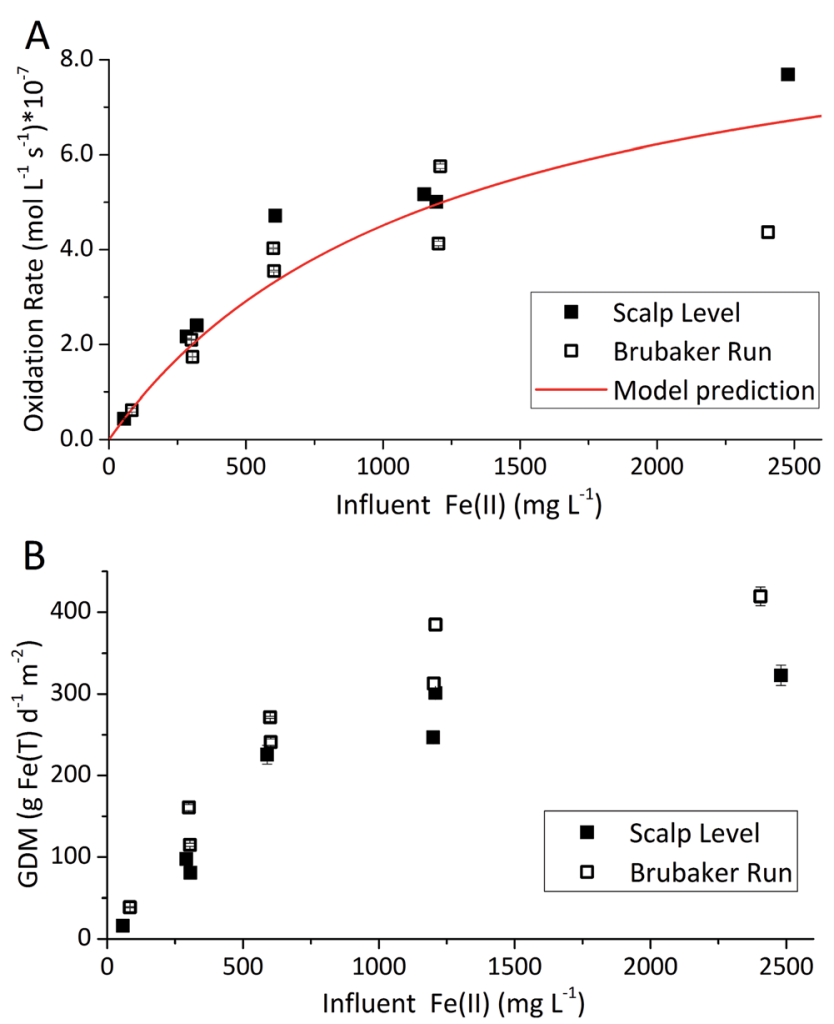

Fig. 3 Influence of influent Fe(॥) set-point on Fe(॥) oxidation and Fe(T) removal obtained for the Scalp Level and Brubaker Run bioreactors hydraulic residence time of $6 \mathrm{~h}$, $\mathrm{pH}$ of 2.7 with Scalp Level, and pH 2.9 with Brubaker Run. Steady-state points of each [Fe(॥)] in series set-point were used to calculate rate of Fe(॥) oxidation shown in (A) and rate of total Fe(T) removal in (B). discharges with relatively high $\mathrm{Fe}(\mathrm{II})$ concentrations (e.g., $\left.>200 \mathrm{mg} \mathrm{L}^{-1}\right)$. Encouragingly, one such bioreactor would become even more effective with higher influent Fe(II) concentrations, waters that are otherwise quite challenging to treat by conventional passive or active treatment operations.

\subsection{Kinetic modeling of biological low-pH Fe(II) oxidation}

A dual-Monod rate formulation was used to model $\mathrm{Fe}$ (II) oxidation kinetics in these bioreactors (eqn (3)). This approach only considered the effect of $\mathrm{pH}$ (i.e., $\left[\mathrm{H}^{+}\right]$) and dissolved $\mathrm{Fe}$ (II) concentration. All other possible effects, e.g., biomass concentration, microbial community structure, concentrations of DO and $\mathrm{Fe}(\mathrm{III})$, and temperature, were not directly considered. Rate dependency on these other parameters was excluded because biogeochemical condition was reasonably controlled in
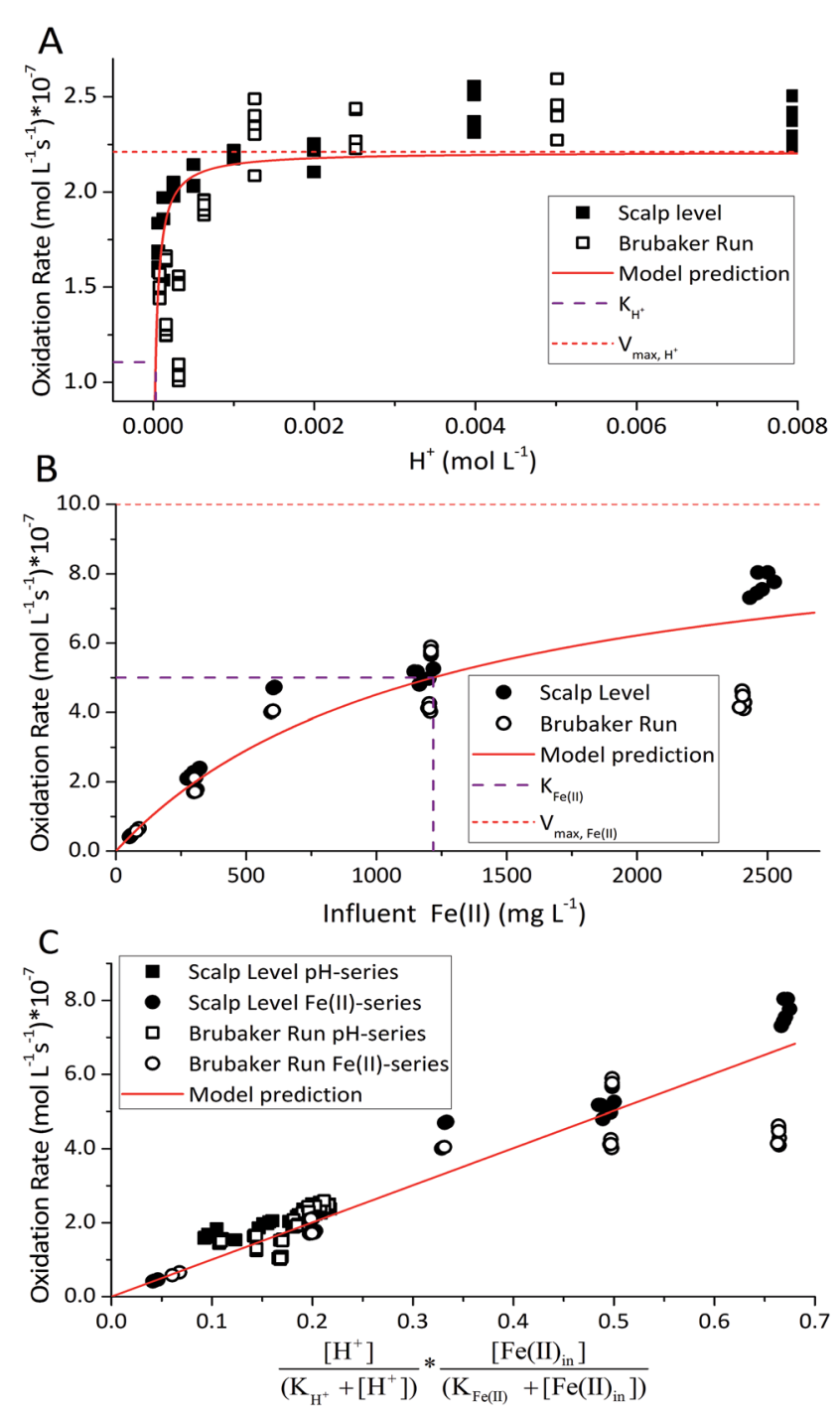

Fig. 4 Parameter estimation for dual-Monod rate law for biological low-pH Fe(॥) oxidation. (A) Fe(॥) oxidation rate versus $\left[\mathrm{H}^{+}\right]$with $[\mathrm{Fe}(॥)]_{\text {in }}$ $=300 \mathrm{mg} \mathrm{L}^{-1}$. (B) Fe(॥) oxidation rate versus $[\mathrm{Fe}(॥)]_{\text {in }}$ with $\mathrm{pH}=2.7$ for Scalp Level or $\mathrm{pH}=2.9$ for Brubaker Run. (C) Fe(॥) oxidation rate versus dual-Monod terms using fixed values for $K_{\mathrm{H}^{+}}=10^{-4.51} \mathrm{M}$ and $\mathrm{K}_{\mathrm{Fe}(I)}=$ $1220 \mathrm{mg} \mathrm{L}^{-1}$. 
a chemostatic system and no significant correlations were found between rates and these parameters. ${ }^{37}$ For example, rates showed no dependence on DO likely because it was never ratelimiting $\left(>3 \mathrm{mg} \mathrm{L}^{-1}\right)$ (ESI Tables S1 and S2 $\dagger$ ) and DO should not be limiting in an aerated reactor. Biomass concentrations likely developed to similar levels as observed in the current study where total biomass concentrations (attached growth and suspended growth) ranged from $0.24 \times 10^{7}$ to $4.84 \times 10^{7}$ cell per $\mathrm{mL}$ in both bioreactor series with $>95 \%$ in the attached growth biofilm. Acidophilic Fe(II) oxidizing bacterial communities evolved in similar ways (primarily controlled by $\mathrm{pH}$ and $\mathrm{Fe}$ concentrations), ${ }^{31}$ and structured differently from the neutral condition enriched Fe(II) oxidizing bacterial communities. ${ }^{38}$ The aggregate effect of all other parameters was effectively lumped into the overall rate constant $k_{\mathrm{bio}}^{*}$ in eqn (3).

For the constrained range of $\mathrm{pH}$ set-points used in this study (pH 2.1-4.2), the proton concentration exerted a distinct saturation-like effect on the $\mathrm{Fe}(\mathrm{II})$ oxidation rate (Fig. 4A). Because protons are not a microbial substrate, a Monod rate formulation is an unconventional formulation. Regardless, for the $\mathrm{pH}$-series experiments (where the influent $\mathrm{Fe}(\mathrm{II})$ concentration was fixed at $300 \mathrm{mg} \mathrm{L}^{-1}$ ), rate parameters were determined using:

$$
R_{\mathrm{Fe}(\mathrm{II})}=\frac{V_{\mathrm{max}, \mathrm{H}^{+}}\left[\mathrm{H}^{+}\right]}{\left(K_{\mathrm{H}^{+}}+\left[\mathrm{H}^{+}\right]\right)}
$$

where $V_{\text {max }, \mathrm{H}^{+}}$is the maximum oxidation rate $\left(\mathrm{mol} \mathrm{Fe}(\mathrm{II}) \mathrm{L}^{-1} \mathrm{~s}^{-1}\right)$ and $K_{\mathrm{H}^{+}}$is the half-saturation coefficient $\left(\mathrm{mol} \mathrm{H}^{+} \mathrm{L}^{-1}\right)$. Rate parameters determined individually from the two bioreactors and from the combined data sets are summarized in Table 2. Graphical fits for these parameters for the individual bioreactors are included in the ESI Fig. S5 and S6. $\dagger$

The influent dissolved Fe(II) concentration (varied from $60-$ $2400 \mathrm{mg} \mathrm{Fe}(\mathrm{II}) \mathrm{L}^{-1}$ ) also exerted a saturation effect on the rate of $\mathrm{Fe}(\mathrm{II})$ oxidation (Fig. 4B). For the influent Fe(II)-series experiments (where the $\mathrm{pH}$ was fixed at 2.7 for the Scalp Level bioreactor and 2.9 for the Brubaker Run bioreactor), rate parameters were determined using:

$$
R_{\mathrm{Fe}(\mathrm{II})}=\frac{V_{\mathrm{max}, \mathrm{Fe}(\mathrm{II})}\left[\mathrm{Fe}(\mathrm{II})_{\text {in }}\right]}{\left(K_{\mathrm{Fe}(\mathrm{II})}+\left[\mathrm{Fe}(\mathbf{I I})_{\text {in }}\right]\right)}
$$

where $V_{\max , \mathrm{Fe}(\mathrm{II})}$ is the maximum oxidation rate (mol $\mathrm{Fe}(\mathrm{II}) \mathrm{L}^{-1}$ $\mathrm{s}^{-1}$ ) and $K_{\mathrm{Fe}(\mathrm{II})}$ is the half-saturation coefficient (mol Fe(II) $\mathrm{L}^{-1}$ ). The overall rate constant $k_{\mathrm{bio}}^{*}$ in eqn (3) was determined after the half-saturation constants for $\mathrm{H}^{+}\left(K_{\mathrm{H}^{+}}\right)$and influent $\mathrm{Fe}(\mathrm{II})\left(K_{\mathrm{Fe}(\mathrm{III})}\right)$ were independently determined from the pH-series and influent Fe(II)-series of experiments, respectively. The graphical fit to determine $k_{\mathrm{bio}}^{*}$ using the combined data sets are shown in Fig. 4C. The $V_{\max }$ terms from eqn (7) and (8) are essentially lumped into $k_{\mathrm{bio}}^{*}$. The objective of our kinetic modeling was to develop a simple approach to predict the rates of low-pH Fe(II) oxidation in an active treatment bioreactor based on measureable characteristics of candidate AMD discharges (i.e., $\mathrm{pH}$ and emergent [Fe(II)]). This model would serve to predict how the biogeochemical processes in the field (e.g., across a TIF) would translocate to a more controlled setting. The reactor design (e.g.,

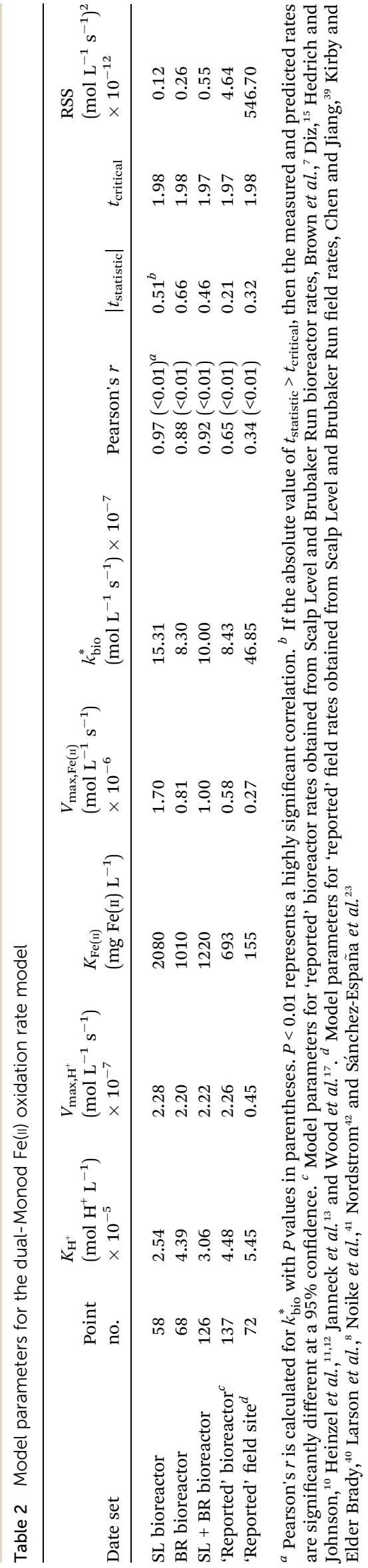


stir tank with limited surface area for attached growth) and operational conditions $\left(e . g ., 20^{\circ} \mathrm{C}, \mathrm{HRT}=6 \mathrm{~h}\right)$ can affect reactor performance yet their impacts are essentially lumped into the rate parameters, possibly limiting the applicability of our model to other AMD systems.

To address this issue, we extracted rates of low-pH Fe(II) oxidation from a number of field sites ${ }^{8,23,39-42}$ and bioreactor studies $^{7,10-13,15,17}$ and used our model to predict corresponding rates $^{39-42}$ (using eqn (3) with rate parameters in Table 2; literature data summarized in ESI Table S3†). In general, rates of $\mathrm{Fe}(\mathrm{II})$ oxidation measured in our bioreactor experiments were lower than those reported in the field (Fig. 5). Consistent with our current study, rates of Fe(II) oxidation displayed a saturation-like dependency on the $\mathrm{H}^{+}$concentration, with fastest rates measured at lowest $\mathrm{pH}$ values (Fig. 5A). Rates of $\mathrm{Fe}(\mathrm{II})$ oxidation from these studies also displayed a saturation-like dependency on the $\mathrm{Fe}$ (II) concentration (Fig. 5B). The slower rates measured in our laboratory experiments were affected by the HRT of the bioreactor. HRT values for water flowing across the field sites were on the order of minutes (Table 1), far from the 6 hour HRT used in our experiments.

Evaluation of biogeochemical kinetics was always challenging because differences in complex hydrogeochemical conditions. To test the applicability of our model to different AMD systems, $\mathrm{pH}$ and influent $\mathrm{Fe}(\mathrm{II})$ concentration were used for bioreactor rates prediction, while $\mathrm{pH}$ and $\mathrm{Fe}(\mathrm{II})$ concentration of emergent AMD was used for field rates prediction when rates were measured across both natural and 'engineered' TIFs in AMD site. ${ }^{8}$ Compiled 'reported' bioreactor rates including current bioreactors (i.e., Scalp Level and Brubaker Run) and literature bioreactors were used to calculate kinetic parameters only for bioreactor rate prediction in Fig. 5C. Similarly, Scalp Level and Brubaker Run field rates and literature field rates were used to calculate kinetic parameters of 'reported' field rates to predict rates measured in different field sites. DualMonod kinetic parameters calculated obtained from different series of Fe(II) oxidation rates were summarized in Table 2.

Most of the bioreactor and field rates of $\mathrm{Fe}(\mathrm{II})$ oxidation were able to be predicted by our dual-Monod kinetic model using two series of kinetic parameters obtained from currently and previously reported bioreactor or field studies (e.g., $k_{\text {bio }}^{*}=8.43 \times 10^{-7} \mathrm{~mol} \mathrm{~L}^{-1} \mathrm{~s}^{-1}$ for bioreactor ratesis; $k_{b i o}^{*}=46.9 \times 10^{-7} \mathrm{~mol} \mathrm{~L}^{-1} \mathrm{~s}^{-1}$ for field rates), while some field rates still tended to be under-predicted (Fig. $5 \mathrm{C}$ ). In other words, by adjusting kinetic parameters $\left[k_{\mathrm{bio}}^{*}, K_{\mathrm{H}^{+}}, K_{\mathrm{Fe}(\mathrm{III}}\right]$, eqn (3) could reasonably predict previously reported results. Statistical analyses were employed to examine the significance of the difference of measured rates versus predicted rates (Table 2). Although $t$ tests demonstrated that pair-wise comparisons between all measured and predicted rates in currently or preciously reported studies were not significantly different at $95 \%$ confidence, as compared to the bioreactors, the residual sum of squares (RSS) between measured rates and predicted rates was much larger when using 'reported' field rates for kinetic parameter calculation. Because of the complicated hydro-biogeochemical dissimilarities among different reactor systems or natural environments, our model may represent
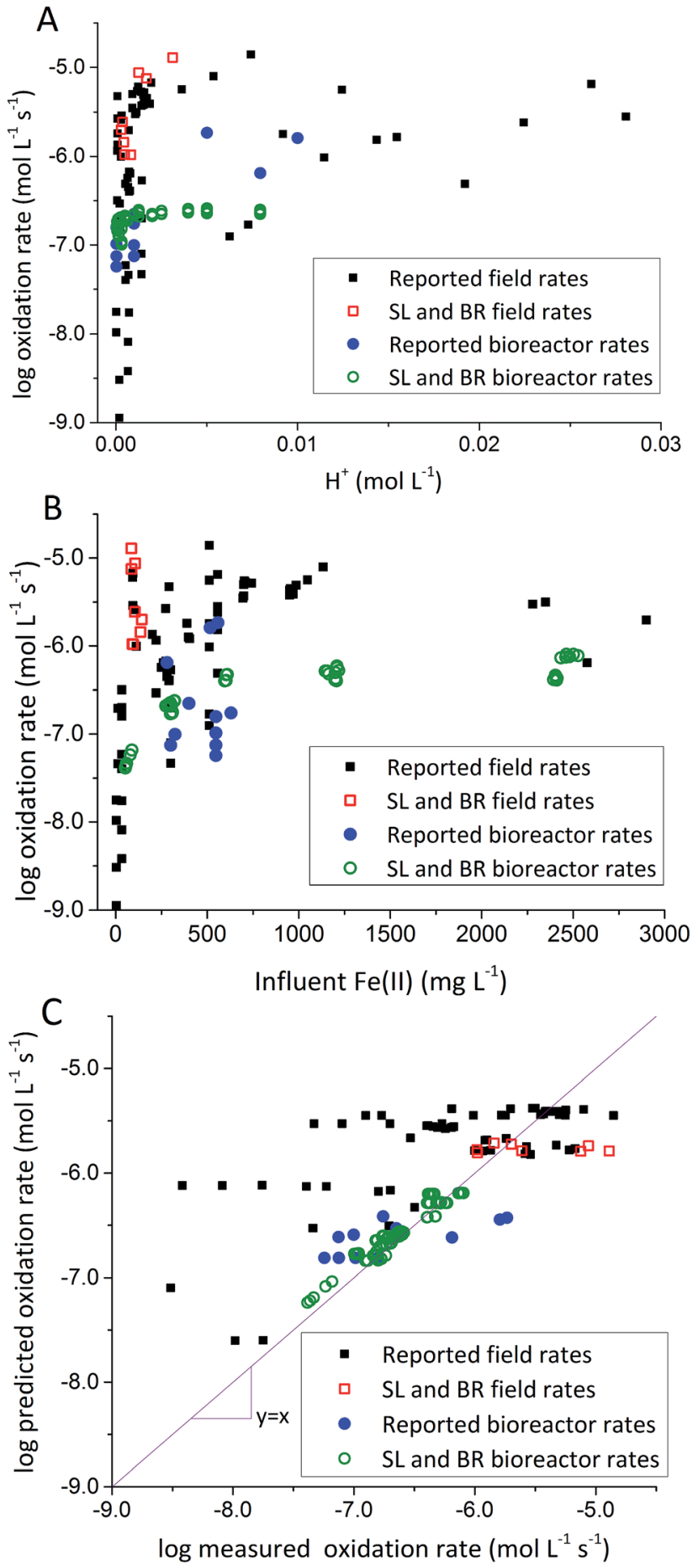

Fig. 5 Comparison of rates measured in the current study with other rates from the literature. (A) Fe(॥) oxidation rates versus $\left[\mathrm{H}^{+}\right]$. (B) $\mathrm{Fe}(॥)$ oxidation rates versus $[\mathrm{Fe}(\|)]_{\text {in. }}$ (C) Predicted rates versus measured rates. Predicted rates calculated using dual-Monod model and parameters obtained from A and B. Reported field rates from Chen and Jiang, ${ }^{39}$ Kirby and Elder Brady, ${ }^{40}$ Larson et al., ${ }^{8}$ Noike et al., ${ }^{41}$ Nordstrom $^{42}$ and Sánchez España et al. ${ }^{23}$ Reported bioreactor rates from Brown et al., ${ }^{7}$ Diz, ${ }^{15}$ Hedrich and Johnson, ${ }^{10}$ Heinzel et al., ${ }^{11,12}$ Janneck et al. ${ }^{13}$ and Wood et al. ${ }^{17}$

a conservative prediction for rates of low-pH Fe(II) oxidation (e.g., in current bioreactor systems with controlled hydrobiogeochemistry). 


\section{Conclusions}

Reported rates of low-pH Fe(II) oxidation from field and bioreactor studies vary over at least four orders of magnitude (Fig. 5). This wide range of rates is likely caused by differences in geochemical conditions ( $\mathrm{pH}$, temperature, [Fe(II)], [Fe(III)], DO), hydrodynamic characteristics (flow rate, turbulence, HRT), microbial community structure, and biomass concentrations. For our well constrained bioreactor systems $\left(T=20^{\circ} \mathrm{C}, \mathrm{HRT}=\right.$ $6 \mathrm{~h}, \mathrm{pH}=2.1$ to 4.2 , [Fe(II) $]_{\text {in }}=80-2400 \mathrm{mg} \mathrm{L}^{-1}$ ), we were able to develop a three-parameter $\left[k_{\mathrm{bio}}^{*}, K_{\mathrm{H}^{+}}, \mathrm{K}_{\mathrm{Fe}(\mathrm{II})}\right]$ dual-Monod rate law (eqn (3), Table 2). While this model still tended to under-predict some field rates using field sites' $\mathrm{pH}$ values and emergent $\mathrm{Fe}$ (II) concentrations, this model should prove useful for predicting rates of $\mathrm{Fe}(\mathrm{II})$ oxidation in engineered bioreactors for active treatment or engineered TIFs sites for passive treatment. Rates of $\mathrm{Fe}(\mathrm{II})$ oxidation (and kinetic parameters) were remarkably similar from two sites that displayed significantly different field rates. Encouragingly, these results could suggest that bioreactor rates will be far less variable than field rates.

Low-pH Fe(II) oxidation and $\mathrm{Fe}(\mathrm{III})$ precipitation occur naturally across TIFs at many AMD sites. While natural TIFs can (and, whenever possible, should) be incorporated into passive AMD treatment systems, active treatment bioreactors are also viable options for select chemistries. In particular, AMD with high dissolved Fe(II) concentrations (e.g., >200 $\mathrm{mg} \mathrm{L}^{-1}$ ) would be very amenable to active treatment. The HRT used in these experiments $(6 \mathrm{~h})$ was relatively long compared to the HRT across field sites and was at least one reason why Fe(II) oxidation rates in our bioreactors were lower than field sites. However, the relatively long HRT used in these experiments may have enhanced the precipitation and capture of Fe(III) (Fig. 2D and 3D). While stimulating a fast rate of $\mathrm{Fe}$ (II) oxidation is important for AMD treatment, removal of $\mathrm{Fe}(\mathrm{T})$ is arguably the most important process in the treatment system. Iron removal rates were found to be as high as 150 to $400 \mathrm{GDM}$ in these bioreactors as compared to $20 \mathrm{GDM}$ for aerobic settling ponds. The mineral purity of $\mathrm{Fe}(\mathrm{III})$ precipitates could be significance of economic value. All of these results point to the promise of a simple approach of enriching indigenous sediment Fe(II)-oxidizing bacteria in bioreactors for AMD treatment.

\section{Conflict of interest}

There are no conflicts of interest to declare.

\section{Acknowledgements}

This work was partially supported by the US Office of Surface Mining Reclamation and Enforcement under Cooperative Agreement S11AC20005, by the China Scholarship Council and China Postdoctoral Science Foundation funded project (2017M610927) (to Y. S.), and by the Appalachian Research Initiative for Environmental Science (ARIES). ARIES is an industrial affiliates program at Virginia Tech, supported by members that include companies in the energy sector. The opinions and recommendations expressed herein are solely those of the authors and do not imply any endorsement by ARIES. We thank Travis Tasker and Lance N. Larson for field assistance.

\section{References}

1 C. A. Cravotta, Appl. Geochem., 2008, 23, 166.

2 C. S. Kirby and C. A. Cravotta, Appl. Geochem., 2005, 20, 1920.

3 A. T. Herlihy, P. R. Kaufmann, M. E. Mitch and D. D. Brown, Water, Air, Soil Pollut., 1990, 50, 91.

4 D. K. Nordstrom, C. N. Alpers, C. J. Ptacek and D. W. Blowes, Environ. Sci. Technol., 2000, 34, 254.

5 Interstate Technology and Regulatory Council, Environmental Council of the States, Washington, DC, http:/www.itrcweb.org/ miningwaste-guidance/decision_tree.htm, retrieved 16 September 2013.

6 D. B. Johnson and K. B. Hallberg, Sci. Total Environ., 2004, 338, 3 .

7 J. F. Brown, D. S. Jones, D. B. Mills, J. L. Macalady and W. D. Burgos, Appl. Environ. Microbiol., 2011, 77, 545.

8 L. N. Larson, J. Sánchez-España and W. Burgos, Appl. Geochem., 2014, 47, 85.

9 T. DeSa, J. Brown and W. Burgos, Mine Water Environ., 2010, 29, 239.

10 S. Hedrich and D. B. Johnson, Bioresour. Technol., 2012, 6, 44.

11 E. Heinzel, S. Hedrich, E. Janneck, F. Glombitza, J. Seifert and M. Schlömann, Appl. Environ. Microbiol., 2009, 75, 858.

12 E. Heinzel, E. Janneck, F. Glombitza, M. Schlömann and J. Seifert, Environ. Sci. Technol., 2009, 43, 6138.

13 E. Janneck, I. Arnold, T. Koch, J. Meyer, D. Burghardt and S. Ehinger, Mine water and innovative thinking, in Proceedings of the international mine water association symposium, ed. C. Wolkersdorfer and A. Freund, ed. Cape Breton University Press, Sydney, NS, Canada, 2010, p. 131.

14 J. S. Tischler, C. Wiacek, E. Janneck and M. Schlömann, Mine Water Environ., 2013, 32, 258.

15 H. R. Diz, Ph.D. dissertation, Virginia Polytechnic Institute and State University, 1997.

16 S. M. Mousavi, S. Yaghmae and A. Jafari, Fuel, 2007, 86, 993. 17 T. A. Wood, K. R. Murray and J. G. Burgess, Appl. Microbiol. Biotechnol., 2001, 56, 560.

18 A. Mazuelos, F. Carranza, I. Palencia and R. Romero, Hydrometallurgy, 2000, 58, 269.

19 Y. Sheng, B. Kaley and W. D. Burgos, Bio-Protoc., 2017, 7(3), DOI: $10.21769 /$ BioProtoc.2130.

20 B. Pesic, D. J. Oliver and P. Wichlacz, Biotechnol. Bioeng., 1989, 33, 428.

21 C. S. Kirby, H. M. Thomas, G. Southam and R. Donald, Appl. Geochem., 1999, 14, 511.

22 L. N. Nikolov and D. G. Karamanev, J. Ferment. Bioeng., 1990, 69, 265.

23 J. Sánchez España, E. López Pamo and E. Santofimia Pastor, J. Geochem. Explor., 2007, 92, 120.

24 W. D. Burgos, T. Borch, L. D. Troyer, F. Luan, L. N. Larson, J. F. Brown, J. Lambson and M. Shimizu, Geochim. Cosmochim. Acta, 2012, 76, 29. 
25 G. R. Watzlaf, K. T. Schroeder, R. L. P. Kleinmann, C. L. Kairies and R. W. Nairn, American Society of Mining and Reclamation, Lexington, Kentucky, 2002.

26 L. L. Stookey, Anal. Chem., 1970, 42, 779.

27 D. R. Lovely and E. J. P. Phillips, Appl. Environ. Microbiol., 1987, 53, 1536-1540.

28 P. C. Singer and W. Stumm, Science, 1970, 167, 1121.

29 W. Sung and J. J. Morgan, Environ. Sci. Technol., 1980, 14, 561.

30 L. N. Larson, J. Sánchez-Españac, B. Kaley, Y. Sheng, K. Bibby and W. Burgos, Environ. Sci. Technol., 2014, 48, 9246.

31 Y. Sheng, K. Bibby, C. Grettenberger, B. Kaley, J. L. Macalady, G. Wang and W. D. Burgos, Appl. Environ. Microbiol., 2016, 82, 3611 .

32 C. L. Grettenberger, A. R. Pearce, K. J. Bibby, D. S. Jones, W. D. Burgos and J. L. Macalady, Appl. Environ. Microbiol., 2017, 83(7), DOI: 10.1128/aem.00015-17.

33 S. Regenspurg, A. Brand and S. Peiffer, Geochim. Cosmochim. Acta, 2004, 68, 1185.
34 T. Peretyazhko, J. M. Zachara, J.-F. Boily, Y. Xia, P. L. Gassman, B. W. Arey and W. D. Burgos, Chem. Geol., 2009, 262, 169.

35 R. S. Hedin and R. W. Nairn, 13th Annual WV Surface Mine Drainage Task Force Symposium, 1992, http:// wvmdtaskforce.com/proceedings/1992.cfm.

36 G. A. Brodie, Case history of Fabious impoundment I and overview of the Tennessee Valley Authority's program, in Constructed Wetlands for Water Quality Improvement, ed. G. A. Moshiri, Lewis Publishers, Boca Raton, FL, 1993, p. 157.

37 B. Kaley, MS thesis, The Pennsylvania State University, University Park, PA, 2013.

38 Y. Liu, C. Feng, N. Chen, Y. Sheng, S. Dong, C. Hao and K. Lei, RSC Adv., 2016, 6, 108375-108383.

39 C. J. Chen and W. T. Jiang, Appl. Geochem., 2012, 27, 1966. 40 C. S. Kirby and J. A. E. Brady, Appl. Geochem., 1998, 13, 509. 41 T. Noike, K. Nakamura and J. Matsumoto, Water Res., 1983, 17, 21.

42 D. K. Nordstrom, Selected Papers in the Hydrologic Sciences, U.S.G.S. Water-Supply Paper, 1985, vol. 2270, p. 113. 